\title{
硝酸アンモニゥムセリウムを用いた
}

\section{炭素-炭素二重結合のニトロ化 ${ }^{122}$}

(1992 年 10 月 20 日受理)

杉山卓

硝酸アンモニウムセリウム $(\mathrm{V})$ を用いて炭素-炭素二重結合にニトロ基を導入する反応に拈いて見い だされるいくつかの特徽を，アルケンとして 1-へキセンを用いて詳しく検討した。この反応において は，(1) ギ酸に代表されるようなカルボン酸の存在が必要である。(2)基質，硝酸アンモニウムセリウム $(\mathbb{N})$ ，カルボン酸および溶媒のほかに，ある添加剤が必要である。添加剤としては電子求引性基を持た ないカルボニル化合物などが好ましい。(3) 反応の間に硝酸アンモニウムセリウム(IV)はギ酸セリウム (III)の一水和物に変換されている。(4)この反応は硝酸アンモニウムセリウム(III)によっても進行し, そ の場合には(2)で述べた添加剤は必要ではない。しかし収率はセリウム( N)化合物を用いたときの方法が 良い結果が得られている。

以上のことから, 本反応は, 硝酸アンモニウムセリウム (III)の中心元素であるセリウム上の硝酸陰イ オンがギ酸イオンによって置き換わり，さらにセリウム元素の近辺で硝酸陰イオンから生じた窒素酸化 物種が炭素-炭素二重結合を攻撃することによって進行するものであると説明できる。

\section{1 粕 言}

少なくとも有機化学の分野では一部の希土類元素が酸化剂や重 合開始剤として用いられていた例を除けば, 1976 年 Deacon ら によって有機水銀化合物と金属イッテルビウムとの金属交換反応 によって生成する二侕の錯体がカルボニル化合物へ求核付加する ことが報告され゙)，また 1977 年に Kagan によるョウ化サマリウ ム（II）を用いた種々の化合物の還元の成功が報告いされるまで, ほとんどこれらの元素が導入されたという報告を見ることはなか った。しかし, Deacon や Kagan の先駆的研究以来, 分雂技術の 向上によりこれらの金属が比校的容易に入手できるようになっ たことと相まって，セリウム，サマリウム拈よびイッテルビウム を中心とした種々の希土類元素の化合物を用いた有機合成反応の 開発についての報告が数多く見られるよらになったら。

京都大学化学研究所, 611 宇治市五ヶ庄

1）この報文を “希土類金属化合物による有機目能基の变換 （第 4 報）”とする.

2）前報(第 3 報), T. Sugiyama，Bull. Inst. Chem. Res., Kyoto Univ., 67, 112(1989).

3) G. B. Deacon, W.D. Raverty, D. G. Vince, J. Organomet. Chem., 135 103(1977).

4) J. L. Namy, P. Girard, H. B. Kagan, Nouv. J. Chim., 1, 5(1977).

5) Tse-Lo Ho, Synthesis, 1973，347；今本恒雄, 俵山吉智, 楠本哲生, 横山正孝, 有合化, 42, 143(1984); John R. Long, Aldrichmica Acta，18,87(1985); 今本恒婎, 有合化， 46, 540(1988); 稻永純二, 有合化， 47, 200 (1989) ; H. B. Kagan, M. Sasaki, J. Collin, Pure \& Appl. Chem., 60, 1725(1988).
著者は，これら希土類元素の化合物，特にその中でも最も豊富 に存在し，かつその使用法の開発が求められているセリウムの化 合物によって媒介される有機化合物の官能基変換について研究を 行い, 幾つかの新しい反応系の開発について報告してきた。それ らには，硝酸アンモニウムセリウム $(\mathrm{N})(\mathrm{CAN})-\mathrm{X}_{2}(\mathrm{X}:$ ：ハロゲ ン）系扣よび $\mathrm{CAN}-\mathrm{X}^{-}$系による芳香族化合物のハロゲン化反 応6), トリフルオ口酢酸セリウム $(\mathrm{N})$-アルコール系によるアント ラセンとその誘尊体の直接アルコキシル化反応"，および, 二重 結合の直接ニトロ化反応系の構筑㫜が含まれる。

ところで脂肪族 =トロ化合物は，二ト口基の強い電子求引性の ために，特鼠な炭素一炭㮃結合形成反応が可能である。また生成 物中のニト口基が他の官能基に容易に変换できるために，有用な

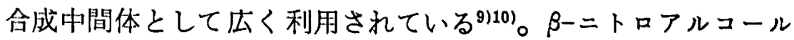
や $\alpha$-ニトロアルケンは, ニトロアルカンとともに最も一般的な ニトロ化合物である。

それらを合成するためには，いくつかの方法が知られている が，その中で最も優れ，また最もよく利用されているものは、ニ

6) T.Sugiyama, Bull. Chem. Soc. Jpn., 54, 2847(1981).

7) T.Sugiyama, Chem. Lett., 1987, 1013.

8) T.Sugiyama, Bull. Inst. Chem. Res., Kyoto Univ., $67,112(1989)$.

9）小野 昇, 加治有恒, 有合化，38，115(1980); 吉越 昭, 有合化, 40, 427(1982)；A. G. M. Barrett, G. G. Graboshi, Chem. Rev., 86, 751(1986); E. J. Cory, H. Estericher, J. Am. Chem. Soc., 100, 6294(1978).

10) H. H. Baver, L. Urbas, "The Chemistry of the Nitro and Nitroso Group", H. Feuer, Ed.; Interscience : New York (1970) part 2, pp. 75 200. 
トロアルカンとフルデヒドを塩基の存在下で反応させる，いわゆ る Henry 法 ${ }^{10)}$ である。

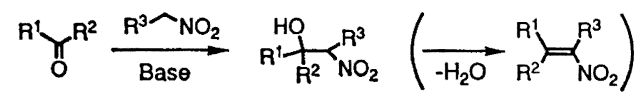

しかし、ニトロ基を含むある分子を合成標的としたときに，ある 中間段階に二トロ基を尊入するためのアルデヒド基を渋築するこ とが容易でないこともしばしばある。また攻慗試薬として目的に 合致するニトロアルカンを得ることが困難な場合もある。したが って,このような場合には, 炭素-炭素二重結合に直接二トロ基 を導入する方法の重要性が增してくる。

炭素-炭素二重結合に直接ニト口基を尊入する試薬としては硝 酸了セチル, 塩化ニトロイル, 二酸化窒素, 三酸化二空素扰よび 硝酸がある!”。しかしここにあげたものの多くは熱に対して不安 定であり, 容易に他の複数の窒素酸化物に分解するため, その取 扱いにもわずらわしさをともならことが多く，そのために，これ らの方法では概して生成物がその分離に大きな労力を要するよう な複雑な混合物となる。また硝酸フセチルには爆発性を有するな どの大きな欠点がある。

前述のように，著者はすでに硝酸アンモニウムセリウム $(\mathrm{N}) を$ 用い中心元素であるセリウム上の配位子を炭素-炭䋕二重結合に

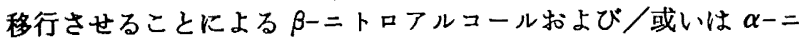
トロアルケンの合成においてその基質適用範用，反応の選択性な どについて報告している8 。同時に，本反応が媒質系に極めて強 い影響を受けること，またこの反応を容易に進行させるためには， 何がしかの添加剤の存在が必要であるといら興味ある事実を見い だしている。

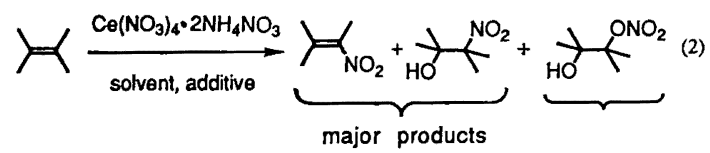

今回著者は硝酸アンモニウムセリウム $(\mathbb{N})$ および硝酸アンモニ ウムセリウム(III)を用いた二重結合の直接ニトロ化反応を詳細に 検討した結果を報告する。

\section{2 実験}

\section{1 测定装置}

試薬の純度確認, 生成物の同定, 定量に用いた装置は次の通り である。

${ }^{1} \mathrm{H}-\mathrm{NMR}$ スベクトル測定には Varian VXR-200 および JEO・ LJNM-GX 400 型核磁気共鳴装瞋を使用した。IR スペクトルは 日立製 260-50 型赤外分光光度計を用いた。GC-MS 测定は Finigan-Mat 社製 ITD-800 Ion Trap Detector を使用した。ガスク ロマトグラフィーによる反応生成物の定量分析は島津 GC-14 A 型 ガスクロマトグラフを使用した（カラム：25 m-0.25 mm $\phi$ PEG$20 \mathrm{M}$ 結合型キャピラリーカラム, カラム温度 $70 \rightarrow 170^{\circ} \mathrm{C}, 3^{\circ} \mathrm{C} /$ $\min$ で昇温, 篡入部温度 $170^{\circ} \mathrm{C}$, FID 検出器部分温度 $170^{\circ} \mathrm{C}$, キャリヤーガス: He $0.9 \mathrm{~kg} / \mathrm{cm}^{2}$, あるいは, カラム: $25 \mathrm{~m}-0.25$

11) H.O. Larson, "The Chemistry of the Nitro and Nitroso Group", H. Feuer, Ed. ; Interscience: New York (1969) part 1, pp. 316-325. $\mathrm{mm} \phi$ OV-1701 キャピラリーカラム, カラム温度 $150^{\circ} \mathrm{C}$ 定温, 導入部温度 $180^{\circ} \mathrm{C}$, FID 検出器部分温度 $180^{\circ} \mathrm{C}$, キャリャーガ ス: He $0.9 \mathrm{~kg} / \mathrm{cm}^{2}$, いずれの場合も内部標準化合物として 1,3 , 5ートリメトキシベンゼンを用いた)。X 線回折スペクトルは島津 製 X線回折装蹎 XD-3 A を用いて得た。

\section{2 試 薬}

硝酸アンモニウムセリウム $(\mathrm{N})$ は, セイミケミカル株式会社か ら提供を受けたものを，反応に使用する前に $80^{\circ} \mathrm{C} て ゙ 2$ 時間乾燥 した後使用した。

標準試料としての 1-ニトロ-2-ヘキサノールは Henry 法に従 ってニトロメタンとハンルアルデヒドから合成した ${ }^{12)}$

同じく標準試料としての 1-ニトロ-1-へキセンは, 1-ニトロー 2-へキサノールから Austin らの方法に従って合成した ${ }^{13)}$ 。それ ぞれの場合, 元素分析, ${ }^{1} \mathrm{H}-\mathrm{NMR}$ スペクトル, IR スペクトル, および毁显スペクトルは湍足すべき結果を与えた。

他の試楽は师肘のものを使用し (Nacalai tesque Inc. および Wako Pure Chemical Industries, LTD.)，必要な場合には精制 した後使用した。

\section{3 反 応例}

2.3.1 硝酸アンモニウムセリウム(IV)による反応 : 硝酸アン モニウムセリウム $(\mathrm{N})(876.8 \mathrm{mg}, 1.6 \mathrm{mmol})$, シクロヘキサノン $(39.2 \mathrm{mg}, 0.4 \mathrm{mmol})$, アセトニトリル $(1.0 \mathrm{ml})$, および 1 -へキ セン $(1.5 \mathrm{ml})$ の泥合物に, キ酸 $(598 \mathrm{mg}, 13.0 \mathrm{mmol})$ を加え, $55 \sim 57^{\circ} \mathrm{C}$ で 17 時間かきまぜた。その後この反応混合物を水 (3 $\mathrm{ml}$ ) のなかへ投入して反応を停止させ，沈股物を沪別した後，ジ クロロメタンで抽出 $(3 \times 3 \mathrm{ml})$ した。ジクロロメタン風を集めて 水で洗浄, 嵌酸水糸ナトリウム水による中和, 無水硫酸ナトリウ ムによる乾燥の後, 減圧下で約 $30 \%$ の容量に濃縮し, 内部標準 物質としての 1，3，5-トリメトキシベンゼンを一定量科量して加 え，ガスクロマトクラフィーによる分析に供した。

2.3.2 硝酸アンモニウムセリウム(III)による反応: 硝酸アン

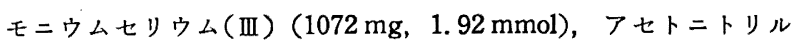
$(1.0 \mathrm{ml})$ および 1-へキセン $(1.5 \mathrm{ml})$ の混合物に, キ酸 (598 $\mathrm{mg}, 13.0 \mathrm{mmol}$ ) を加え, $55 \sim 57^{\circ} \mathrm{C} て ゙ 17$ 時間かきまぜながら 反応させた。次いでこの反応混合物を硝酸アンモニウムセリウム （N）の場合（夹験項: 2.3.1）と同様に処理しガスクロマトグラ フィーによる分析に供した。

\section{4 セリウム化合物の目視実験}

未知試料 $200 \mathrm{mg}$ を浱硫酸/水 $(1 / 1, \mathrm{v} / \mathrm{v}) 20 \mathrm{ml}$ に溶かした溶 液（A溶液）を調製した。

一方, 基準化合物として $\mathrm{Ce}\left(\mathrm{NO}_{3}\right)_{4}$ を $5.8 \mathrm{mg}$ 科量し漕硫酸/ 水 $(1 / 1, v / v) 200 \mathrm{~m} l$ に溶かした溶液（B溶液）を調製し，その $20 \mathrm{ml}$ と A 溶液 $20 \mathrm{ml}$ とを目視により比較した。その結果, $\mathrm{A}$ 溶 液は無色透明, B溶液は淡黄色（溶媒和したセリウム（N)イオン の色）を示すことを確噁した。この結果から本未知陚料中のセり ウム $(\mathrm{N})$ イオンの量は $0.14 \%$ 以下であることが算出された。

\section{5 湿式法による未知試料中のセリウム含量の測定}

未知試料 $100 \mathrm{mg}$ を科量し, 峘硝酸/水 $(1 / 1, v / v) 5 \mathrm{ml}$ に溶か

12) F. I. Carroll, J.D. White, M.E.Wall, J. Am. Chem. Soc., 85, 1236(1963).

13) C. A. Sprang, E. F. Degering, J. Am. Chem. Soc., 64, 1063(1942). 
し，水で全量を $50 \mathrm{ml}$ にした。次にその溶液の $10 \mathrm{~m} l$ を分取しさ らに水で全量を $100 \mathrm{ml}$ に希釈し, へキサミン $5 \mathrm{~g}$ を加え $\mathrm{pH}$ 5.5〜5. 8 に調証した後, キシレノールオレンジを指示蒋として 0.01 M EDTA 溶液を用いてこの夜を滴定した。この結果から, 試料中のセリウム元素の显は, 試料全体の $41.40 \%$ を占めるこ とが算出された。

\section{6 焼成実験による未知試料中のセリウム含量の測定}

未知試料 $100 \mathrm{mg}$ を空気雲团気下, 電気炬中烧成温度 $950^{\circ} \mathrm{C}$ で 1 時間焼成した。その結果残留物として $51.00 \mathrm{mg}$ の固形物 が得られた。この結果から, 本試料中のセリウム元素の含㣟が $41.52 \%$ と算出された。

\section{7 ギ酸セリウムの合成}

$99 \%$ キ酸 $3 \mathrm{ml}$ に水 $35 \mathrm{ml}$ を加え, このものに湃アンモ二ア水/ 水 $(1 / 1, \mathrm{v} / \mathrm{v}) 12 \mathrm{ml}$ を加え $\mathrm{pH} 6.5$ に調整した。次いでこの溶液 に $\mathrm{CeCl}_{3} \cdot 7 \mathrm{H}_{2} \mathrm{O}$ を $7.37 \mathrm{~g}$ 加えた。生成した白色沈股を汇別し， 水で洗浮した後 $105 \pm 5{ }^{\circ} \mathrm{C}$ で 2 時間乾燥した。烧成实験 (2.6 参 照）によって行われたこのもののセリウム分析值は $47.56 \%$ であ った $\left(\mathrm{Ce}(\mathrm{HCOO})_{3} \cdot \mathrm{H}_{2} \mathrm{O}\right.$ に対する理論值 : $\left.47.80 \%\right)$ 。

\section{3 結 果と考察}

\section{1 媒留の検討}

従来報告されている硝酸アンモニウムセリウム $(\mathrm{N}) を$ 用いる反 応系においてしばしば用いられている溶媒としては, アセトニト リル, 水, テトラヒドロフラン, 酢酸, メタノールなどがある。 しかし, 本反応に関してはこれらの溶媒中では極めて不渾足な結 果しか得られていない。たとえば, アルケン基質として 1-へキ センを用いた場合, 最も良い結果が得られたフセトニトリル中で の反応に拈いても， $18 \%$ の相当する $\alpha$-ニトロアルケンと $22 \%$ の $\beta$-ニトロアルコールが得られたにすぎない。基質のアルケン を溶媒として使用した場合，あるいはその他の溶媒（たとえばイ ソオクタン, ジィチルスルホキシドなど）を使用した場合には, さらに低い収率でしか生成物が得られなかった。

そこで著者は，これらの溶媒を組み合わせた二成分系からなる 溶媒を検討した。その結果アセトニトリルーキ酸系を使用した場 合に著しく改良された結果が得られた。すなわち，86\%の収梁で 1ーニトロー1ーヘキセンが，また $91 \%$ の収率で 1-ニトロー2-ヘキサ ノールが得られた8)。

これらの結果をふまえて著者は，アセトニトリルーギ酸の混合 溶媒系がこの反応に対して特異的なものか，あるいはてセトニト リルーカルボン酸の混合溶媒系が本反応にとって好ましい結果を 与えるといら一般的な傾向が見られるのかどらかを知るために, アセトニトリルと種々のカルボン酸からなる二成分系の溶媒がこ の反応に及ぼす影響を検討した。

反応は $57 \sim 59^{\circ} \mathrm{C}$ で CAN $(1.6 \mathrm{mmol}), 1$-ヘキセン $(1.5 \mathrm{ml}$, 大過剩）アセトニトリル $(1.0 \mathrm{ml})$, 怙よびカルボン酸 $(13.0$ $\mathrm{mmol})$ の混合物にシクロヘキサノン $(0.4 \mathrm{mmol})$ を加え，17 時 間かきまぜることによって行った。

その結果を表 1 に要約する。

それによると一般的に小さな $\mathrm{p} K_{\mathrm{a}}$ 值を有する酸が良好な結果 を与えている。この傾向は塩素化酢酸を用いた坋合, トリク口

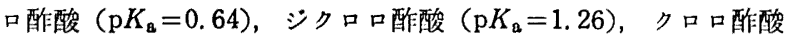
$\left(\mathrm{p} K_{\mathrm{a}}=2.78\right)$ と順次

Table 1 Effect of reaction medium : $\mathrm{RCOOH}$
$\mathrm{Ce}\left(\mathrm{NO}_{3}\right)_{4} \cdot 2 \mathrm{NH}_{4} \mathrm{NO}_{3}: 1.6 \mathrm{mmol}$
$\mathrm{CH}_{3} \mathrm{CN}: 1.0 \mathrm{ml}$
$\mathrm{RCOOH}: 13.0 \mathrm{mmol}$

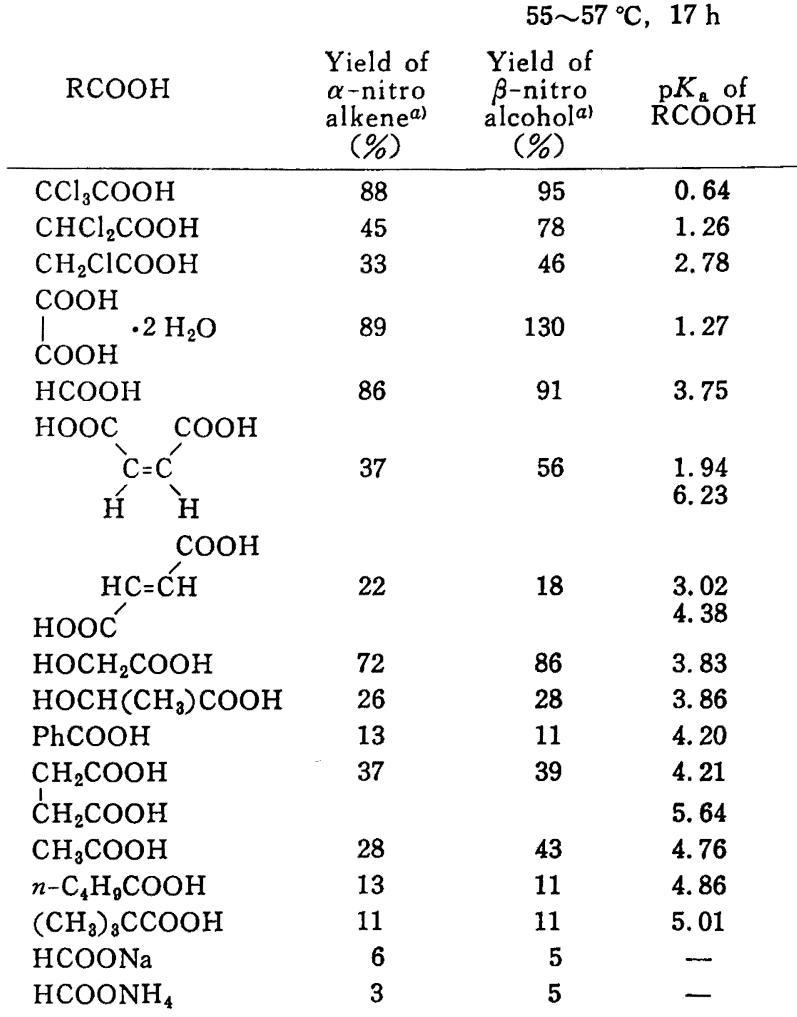

a) The yields are based on CAN used.

収率が減少するといら帮実によって明らかである。 $\mathrm{p} K_{\mathrm{a}}$ が 4.20 以上の酸に関しては，その構造の如何にかかわらず良い結果は得 られていない。

また, シクロ口醀酸 $\left(\mathrm{p} K_{\mathrm{a}}=1.26\right)$ とシュウ酸の二水和物 $\left(\mathrm{p} K_{\mathrm{a}}\right.$ $=1.27)$ は，同程度の $\mathrm{p} K_{\mathrm{a}}$ 値を有するが，前者が $45 \%$ の収率 で $\alpha$-ニトロアルケンと $78 \%$ の収率で $\beta$ ーニトロフルコールを与 えるのに対し, 後者は $89 \%$ の $\alpha$-ニトロアルケンと $130 \%$ の $\beta$-ニトロアルコールを与える。

マレイン酸やフマル酸による結果と両者よりも大きな $\mathrm{p} K_{\mathrm{a}}$ 值 を有するギ酸による結果との比較, 安息香酸による結果とコハク 酸による結果との比較は，いずれも酸分子内の二重結合や芳香環 の $\pi$-電子の存在が，先に述べた酸分子内の八ロダン元素の存在 と同様に，この反応の促進に対して負の結果を与えていることが 明らかである。

分子内のヒドロキシル基は，とくにこの反応に大きな影響を与 えているよらには見えないが，注同じ $\mathrm{p} K_{\mathrm{a}}$ 值を有するグリコ 一ル酸と乳酸との比校によって示されるよらに, 分子の型や大き さもまたこの反応に影響を及ぼしているように思われる。

これまで述べてきた酸に関するいくつかの因子は, 同時に二ト ロアルケンとニトロアルコールの生成比にも何がしかの影響を及 ぢしているよらに見えるがそれについて論ずるにはさらに系統的 な砳究が必要である。

さらにギ酸ナトリウムやギ酸アンモニウムを酸の代わりに用い 
た反応ではいずれの生成物に対しても，数\%程度の収率しか得ら れていないことは，この反応汶対して必要なものがカルボキシラ 一トイオン部分だけでなくカルボン酸であることを示している。

\section{2 反応終了後のセリウム化合物の同定}

溶媒系がこの反応に及ぼす影響から考えて反応に用いた硝酸了

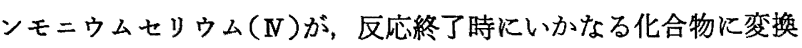
されているかといら問題について調べることは，非常に興味ある ことと思われる。したがって，代表的な例としてアセトニトリルー キ酸系を用いた反応系での反応終了時に打りるセりウム化合物の 分析を試みた。すなわち，生成した沈殿を洰別し，これを少量の ジロロメタンで 3 回洗净した後、ロータリーエバポレーターを 用い减圧 $(20 \mathrm{mmHg})$ 下 $60^{\circ} \mathrm{C}$ で徬燥した。

この試料を硫酸水溶液にとかした溶液と，セリウム(N)イオン を含む硫酸隶溶液とを目視により比較したところ，この未知試料 中のセリウム $(\mathrm{N})$ イオンは $0.14 \%$ 以下であり，セリウム元素は すべてセリウム(III)イオンの形で含まれていることがわからた。

一方, この未知試料をキシレノールオレンジを指示薬として $0.01 \mathrm{M}$ EDTA 溶液を用いて商定した結果，試料中のセリウム元 素の量は $41.40 \%$ であると判明した ${ }^{14)}$ 。たた同試料を空気中電気 姖を用いて $950^{\circ} \mathrm{C}$ に拉いて一時間焼成したところ，固形成分が 得られ，秤量の結果その重量は狫成前の重量の $51.00 \%$ であっ

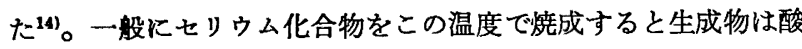
化セリウム $\mathrm{CeO}_{2}$ であることが知られているから，この未知試料 中のセリウム元素の含量は $41.52 \%$ であり，上記の湿式法による 結果と一致した。

一方, この試料に対する炭素, 窒素, 水素の分析值はそれぞれ， 12.21，4.41，1.81\% であった。

さらに pH 6.5 でキ酸, フンモニア水および $\mathrm{CeCl}_{3}$ から別途合 成した白色の沈殿を沪過水洗後 $105 \pm 5^{\circ} \mathrm{C}$ で乾燥したものの X線 回折のピークと, 本試料のX線回折スペクトルのピークがまった く一致したことからこの試料にはキ酸セリウムが含まれている と判断した（図 1)。

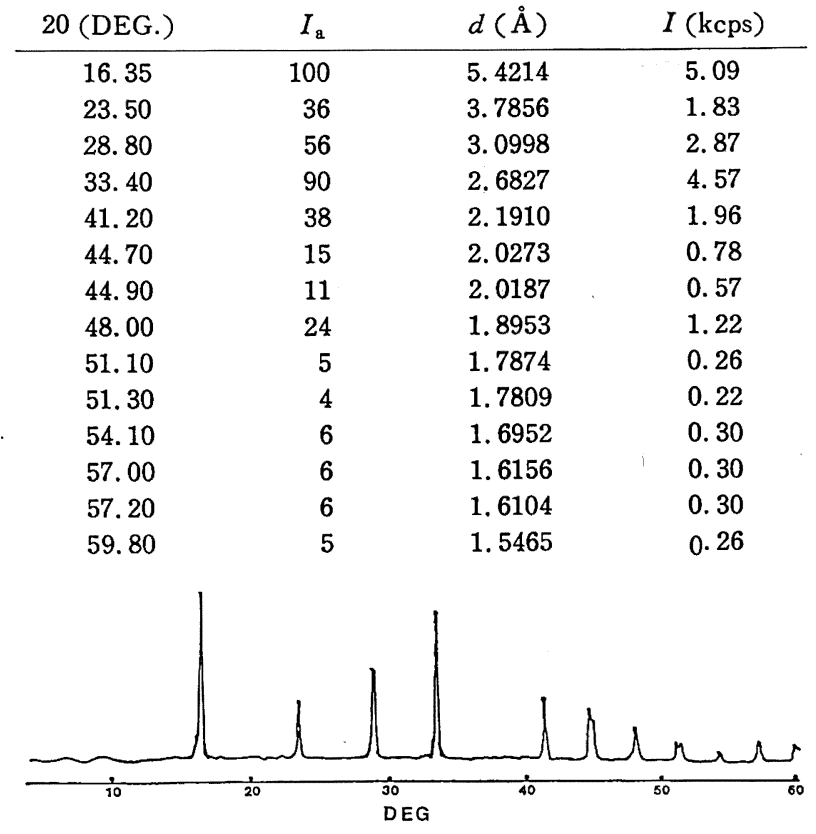

Fig. 1 X-Ray diffraction pattern of the precipitate from the present reaction

さらに上記の別途合成した試料を水で洗浄した後, 乾燥し再度 炭素, 窒素, 水素の元素分析を行うとそれぞれ $12.84 \% ， 0.40 \%$ ， $1.31 \%$ の值を示した。また $2.303 \mathrm{mg}$ の試料に対し $1.382 \mathrm{mg}$ の 灰分が得られた。これらの值は $\mathrm{CeC}_{3} \mathrm{H}_{5} \mathrm{O}_{7}$ 飞相当する。

したがって,このX線回折の結果, 試料中のセリウム含量に関 する分析結果, CHN 元素分析の結果拉よび合成反応系を考兄合 わせると，このニトロ化反応に批いては硝酸アンモニウムセリウ $厶(\mathrm{~N})$ は $\mathrm{Ce}(\mathrm{HCOO})_{3} \cdot 0.5 \mathrm{NH}_{4} \mathrm{NO}_{3} \cdot \mathrm{H}_{2} \mathrm{O}$ の構造を有するギ酸 セリウム誘導体に変换されていることが明らかになった。これら の結果を四式 1 にまとめる。
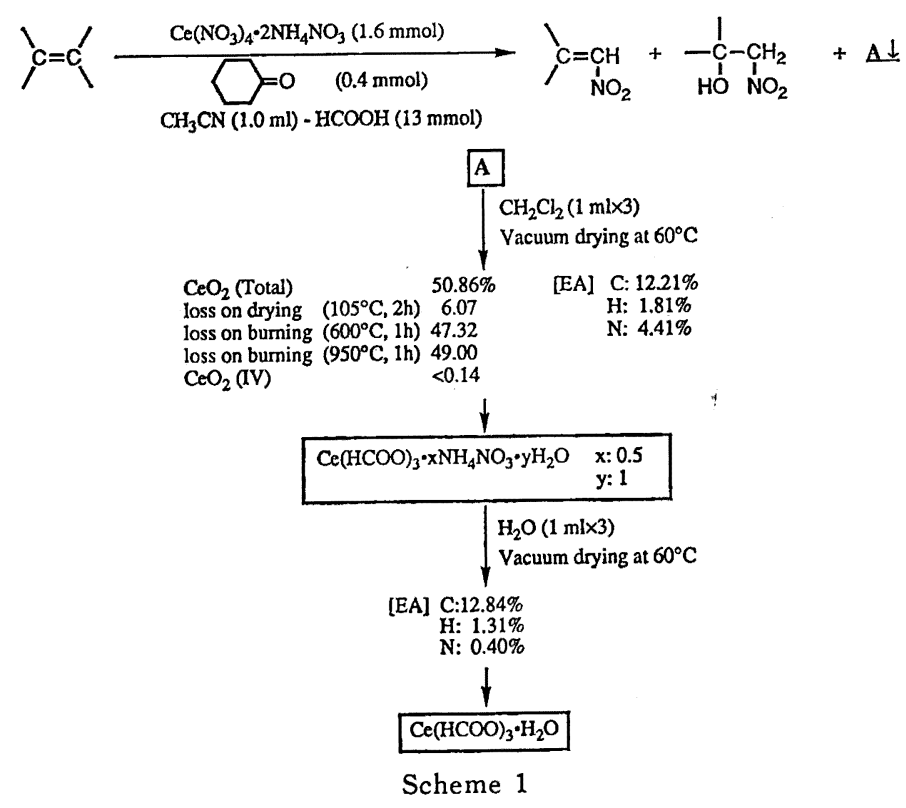

14）本末知試料にはセリウム以外の金属イオンは含まれていない. 
Table 2 Reaction of cerium compounds with formic acid

\begin{tabular}{|c|c|c|c|c|}
\hline $\begin{array}{l}99 \% \text { HCOOH } \\
(\mathrm{ml})\end{array}$ & $\begin{array}{l}\mathrm{CH}_{3} \mathrm{CN} \\
(\mathrm{ml})\end{array}$ & $\begin{array}{l}\mathrm{Ce}\left(\mathrm{NO}_{3}\right)_{4}{ }^{\circ} \\
2 \mathrm{NH}_{4} \mathrm{NO}_{3} \\
(\mathrm{~g})\end{array}$ & $\begin{array}{l}\mathrm{Ce}\left(\mathrm{NO}_{3}\right)_{3}{ }^{\circ} \\
2 \mathrm{NH}_{4} \mathrm{NO}_{3} \cdot \\
4 \mathrm{H}_{2} \mathrm{O}(\mathrm{g})\end{array}$ & Results \\
\hline 6.0 & 0 & 10.5 & - & \multirow{2}{*}{ No reaction at $100^{\circ} \mathrm{C}$} \\
\hline 6.0 & 12.0 & 10.5 & - & \\
\hline 3.0 & 0 & - & 5.2 & $\begin{array}{l}\text { Slow reaction at } 25^{\circ} \mathrm{C} \\
\text { Vigorous reaction at } 56^{\circ} \mathrm{C} \\
\mathrm{NO}_{2} \text { gas evolution }\end{array}$ \\
\hline 3.0 & 6.0 & - & 5.2 & $\begin{array}{l}\text { Slow reaction at } 56{ }^{\circ} \mathrm{C} \\
\mathrm{NO}_{2} \text { gas evolution }\end{array}$ \\
\hline
\end{tabular}

3.3 硝酸アンモニウムセリウム(III)および硝酸アンモニウム セリウム(IV) とキ酸の反応

種々の条件下に打ける硝酸アンモニウムセリウム (N)とギ酸と の反応において生成したセリウム化合物の分析結果はそのセリウ ム化合物がギ酸セリウム(III)の一水和物であり，そのことは中心 原子セリウム上のもともとの配位子である硝酸陰イオンが新しい 配位子キ酸イオンによって置き換えられギ酸セリウム(III)が生成 することによって反応が進行することを示唆している。したがっ てこの点をさらに確かめるために, 著者は硝酸アンモニウムセリ ウム (N) と硝酸アンモニウムセリウム (III) をそれぞれ別個に,

種々の条件下でギ酸と反応させその結果を観察した。

表 2 に要約されているそれらの結果は大変興味のある事実を示 している。すなわち, 硝酸アンモニウムセリウム (NV) は, 溶媒 としてのアセトニトリルの存在の有無にかかわらず, 反応温度 $100{ }^{\circ} \mathrm{C}$ に怙いてすらギ酸と反応しないことがわかった。一方, こ れとは逆に硝酸アンモニウムセリウム(III) とギ酸を混合し, そ の温度を上昇させると $25^{\circ} \mathrm{C}$ から温度の上昇にともない少しずつ 反応が始まり, 温度が $56^{\circ} \mathrm{C}$ に達すると急激に反応が進行して $\mathrm{NO}_{2}$ ガスが発生する。アセトニトリル中での反応においても同 じ結果を示すが, この場合は $56^{\circ} \mathrm{C}$ からっくりと反応を開始し 同様に $\mathrm{NO}_{2}$ ガスを発生する。

おそらく, 硝酸アンモニウムセリウム (N) は, 非水系溶媒中で は $\mathrm{Ce}(\mathrm{N})$ が $\mathrm{NO}_{3}$ と強い錯体を形成することによって,これ自 身がギ酸の攻撃を受けることなく, 配位子交換が起こらないので あろら。

\section{4 本反応系における添加剤の作用}

先の報文で著者は, 本反応を容易に進行させるためには, たと えばシクロへキサノンのような化合物の添加が必要であることを 見いた゚したことを報告した8)。この一部を表 3 に示す。

1一ヘキセンと硝酸アンモニウムセリウム $(\mathrm{N})$ との反応に拉い て, 添加剤を加えない場合には相当するニトロアルコールおよび ニトロアルケンがそれぞれ $1 \%$ と $6 \%$ の収率で得られたにすぎ ないのに対し, 硝酸アンモニウムセリウム(N) $1.6 \mathrm{mmol}$ に対し て $0.4 \mathrm{mmol}$ のシクロヘキサノンを反応系に加える之, ニトロア ルコールが $91 \%$ ：トトアルケンが $86 \%$ の収率でそれぞれ得ら れる。このような著しい反応促進効果は, 他の簡単な直鎖状のカ ルボニル化合物や環状の飽和カルボニル化合物においても見られ る。セリウムイオンが酸素親和性を示すことはよく知られた事㬰 である。したがってカルボニル化合物以外の添加剤としていくつ かのエーテル, アルコール怙よびスルホキシドを検討したが, 何 れも生成物は $10 \%$ 以下の収率でしか得られなかった8)。またそ のほかにも分子内に酸素元素を含まない芳香族炭化水素, スルフ
Table 3 Effect of additive in the reaction with 1exene $^{a / 8)}$

\begin{tabular}{lcc} 
Additive & $\begin{array}{c}\text { Yield of } \\
\text { 1-nitro-1-hexene } \\
(\%)^{b}\end{array}$ & $\begin{array}{c}\text { Yield of } \\
\text { 1-nitro-2-hexanol } \\
(\%)^{b)}\end{array}$ \\
\hline Cyclohexanone & 6 & 1 \\
Cyclopentanone & 32 & 157 \\
Acetophenone & 30 & 145 \\
1-Heptanone & 20 & 19 \\
Acetylacetone & 66 & 87 \\
Hexachloroacetone & 52 & 103 \\
Dibutyl ether & 10 & 4 \\
Tetrahydrofuran & 1 & 0 \\
1-Propanol & 5 & 0 \\
Hydroquinone & 3 & 0 \\
Cumene & 39 & 107 \\
Benzene & 12 & 6 \\
Dibuty'l sulfide & 4 & 0 \\
Dimethyl sulfoxide & 7 & 4 \\
Chloroform & 10 & 5 \\
Benzhydrol & 9 & 3 \\
& 18 & 6
\end{tabular}

a) The reaction was carried out under the following conditions ; CAN : $1.6 \mathrm{mmol}, 1$-hexene : $1.5 \mathrm{ml}$, $\mathrm{CH}_{3} \mathrm{CN}: 1.0 \mathrm{ml}$, $\mathrm{HCOOH}: 13.0 \mathrm{mmol}$, additive : $0.4 \mathrm{mmol}, 55 \sim 57^{\circ} \mathrm{C}, 17 \mathrm{~h}$.

b) The yields are based on CAN used.

ィドおよび脂肪族ハロゲン化物を検討したが，いずれの場合も好 ましい結果が得られなかった。

これらの結果は, 概して, カルボニル基を有する化合物がこの 反応の促進に大きな影響を与えていることを示しているよらにみ える。しかし，この推測は必ずしも正しくない。なぜならばへキ サクロロアセトンのよらに多くのハロゲン原子を有するケトンの この反応を促進する能力は, 極めて小さいからである(二トロア ルケンの収率 $10 \%$ ，ニトロアルコールの収率 $4 \%$ )。この事実は カルボニル酸素上に，ある量以上の電子密度があることが必要で あるといらことを示している。

先に述べた硝酸アンモニウムセリウム(III) のみがギ酸と反応 し，硝酸アンモニウムセリウム $(\mathrm{N})$ はキ酸とまったく反応しない といら結果は，この反応における，たとえばシクロへキサノンの ような添加剤の作用を説明するのに十分な結果である。すなわら 硝酸アンモニウムセリウム $(\mathrm{N})$ がこれらのカルボニル化合物によ って還元され硝酸アンモニウムセリウム(III)に変換された後, ギ 酸と反応していることは明らかである。また, 同時にそのことは, ギ酸あるいはそれに相当する酸の存在下でのみ反応が容易に進行 
ナることも説明している。

この反応がケトンのような有機化合物が存在しない場合でも二 ッケルのよらなある金属粉が存在すると進行することも上記の還 元後の配位子交換といら結諭と矛盾するものではない。

3.5 硐酸アンモニウムセリウム(III)によるアルケンのニトロ 化反応

3.4 において得られた結論は，硝酸アンモニウムセリウム $(N)$ の代わりに硝酸アンモニウムセリウム（III)を用いるならば，添加 郕の存在しない状態でも反応が容易に進行するであるらことを示 唆している。したがって著者は, 現在まで比校的良い結果が得ら れているいくつかの条件下で, 硝酸アンモニウムセリウム (III) と 1ーヘキセンとの反応を行い，硝酸アンモニウムセリウム $(\mathrm{N}) を$ 用 いた場合との比較を試みた。

表 4 にその結果をまとめる。予想通り反応は容易に進行するこ とが認められた。しかしながら，用いた溶媒の種類にかかわらず， また酸としてキ酸を用いた場合も，トリフルオ口酭酸を用いた場 合もいずれの場合においても硝酸フンモニウムセリウム $(\mathrm{N})$ を用 いた场合の方が，硝酸アンモニウムセリウム（III）を用いた場合よ りむ高い収率で生成物が得られている。この反応はセりウム元素 上の配位子が炭素-炭秦二重結合に移行する反応であるから, 渋
度的な問題として両せりウム化合物上の硝酸イオンの数を考虙し なければならない。run 3 に执いては，硝酸アンモニウムセリウ ム(III) を通常の $1.60 \mathrm{mmol} の 1.2$ 倍の $1.92 \mathrm{mmol}$ 使用するこ とによって，この補正を行っているが，その場合に扰いても硝酸 アンモニウムセリウム (N)（1.60 mmol）を用いた方が好結果を 与えている。

この結果は，反応のいずれかの段階に拈いて硝酸アンモニウム セリウム $(\mathrm{N})$ またはそれに由来するセリウム $(\mathrm{N})$ 錯体がこの反応 に何らかの影繁を持っていることを示しているよらに思えるが， これたけの結果からは結諭を得ることは出来ない。

また run 4 ではセリウム(III)化合物を用いた場合に，添加剤と してシクロへキサノンを共存させた結果を示しているが，この場 合には負の効果を与えている。

\section{6 溶媒の非酸成分の検討}

本反応は今まで主としてアセトニトリルー有機酸系で行われて きた。これに対して表 5 はギ酸を用い，この二成分系の内の非酸 成分を種々の化合物に変えて，その反応系に拉よほす寸影整を検討 した結果を示している。この結果からみると、アセトニトリルや ブロピオニトリルのよらな短鎖のニトリルやニトロメタンを使用 した婸合に好結果を与えることがわかる。

Table 4 Comparison of results by $\mathrm{Ce}(\mathrm{N})$ with those by $\mathrm{Ce}(\mathrm{III})$

Ce compound : $1.6 \mathrm{mmol}$, 1-Hexene $: 1.5 \mathrm{ml}$

Solvent : $1.0 \mathrm{ml}$, (Cyclohexanone)

Acid : $13.0 \mathrm{mmol}, \quad 55 \sim 57^{\circ} \mathrm{C}, 17 \mathrm{~h}$

\begin{tabular}{|c|c|c|c|c|c|c|}
\hline Run & Ce compound & Solvent & Acid & (mmol) & $\begin{array}{c}\text { Yield of } \\
\text { 1-nitro- } \\
\text { 1-hexene } \\
(\%)\end{array}$ & $\begin{array}{l}\text { Yield of } \\
\text { 1-nitro- } \\
\text { 2-hexanola) } \\
(\%)\end{array}$ \\
\hline 1 & $\mathrm{Ce}(\mathrm{N})^{b)}$ & $\mathrm{CH}_{3} \mathrm{CN}$ & $\mathrm{HCOOH}$ & 0.4 & 86 & 91 \\
\hline 2 & $\mathrm{Ce}(\mathrm{III})^{\mathrm{c})}$ & $\mathrm{CH}_{8} \mathrm{CN}$ & $\mathrm{HCOOH}$ & - & 38 & 42 \\
\hline 3 & $\left.\mathrm{Ce}(\text { III })^{d}\right)$ & $\mathrm{CH}_{3} \mathrm{CN}$ & $\mathrm{HCOOH}$ & - & 50 & 42 \\
\hline 4 & $\mathrm{Ce}($ III $)$ & $\mathrm{CH}_{3} \mathrm{CN}$ & $\mathrm{HCOOH}$ & 0.4 & 28 & 32 \\
\hline 5 & $\mathrm{Ce}(\mathrm{N})$ & $\mathrm{CH}_{8} \mathrm{CN}$ & $\mathrm{CF}_{3} \mathrm{COOH}$ & 0.4 & 102 & 94 \\
\hline 6 & $\mathrm{Ce}$ (III) & $\mathrm{CH}_{3} \mathrm{CN}$ & $\mathrm{CF}_{3} \mathrm{COOH}$ & - & 24 & 20 \\
\hline 7 & $\mathrm{Ce}(\mathrm{N})$ & $\mathrm{CH}_{3} \mathrm{NO}_{2}$ & $\mathrm{HCOOH}$ & 0.4 & 69 & 64 \\
\hline 8 & $\mathrm{Ce}$ (III) & $\mathrm{CH}_{8} \mathrm{NO}_{2}$ & $\mathrm{HCOOH}$ & - & 28 & 20 \\
\hline
\end{tabular}

a) The yields are based on $\mathrm{CAN}$ used.

b) $\mathrm{Ce}(\mathrm{N}): \mathrm{Ce}\left(\mathrm{NO}_{3}\right)_{4} \cdot 2 \mathrm{NH}_{4} \mathrm{NO}_{3}$.

c) $\mathrm{Ce}$ (III): $\mathrm{Ce}\left(\mathrm{NO}_{3}\right)_{3} \cdot 2 \mathrm{NH}_{4} \mathrm{NO}_{3} \cdot 4 \mathrm{H}_{2} \mathrm{O}$.

d) $\mathrm{Ce}($ III) $: 1.92 \mathrm{mmol}$.

Table 5 Effect of reaction medium : non-acid component

$\mathrm{Ce}\left(\mathrm{NO}_{3}\right)_{4} \cdot 2 \mathrm{NH}_{4} \mathrm{NO}_{3}: 1.60 \mathrm{mmol}, 1-$ Hexene $: 1.5 \mathrm{ml}, \square=0: 0.4 \mathrm{mmol}$

$\mathrm{HCOOH}: 13.0 \mathrm{mmol}$, non-acid component : $1.0 \mathrm{ml}, 55 \sim 57^{\circ} \mathrm{C}, 17 \mathrm{~h}$

\begin{tabular}{lccccc}
$\begin{array}{c}\text { Non-acid } \\
\text { component }\end{array}$ & $\begin{array}{c}\text { Yield of } \\
\alpha-n i t r o \\
\text { alkene } \\
(\%)\end{array}$ & $\begin{array}{c}\text { Yield of } \\
\beta-n i t r o \\
\text { alcohol } \\
(\%)\end{array}$ & $\begin{array}{c}\text { Non-acid } \\
\text { component }\end{array}$ & $\begin{array}{c}\text { Yield of } \\
\alpha \text {-nitro } \\
\text { alkene } \\
(\%)\end{array}$ & $\begin{array}{c}\text { Yield of } \\
\beta \text {-nitro } \\
\text { alcohola) } \\
(\%)\end{array}$ \\
\hline $\mathrm{CH}_{3} \mathrm{CN}$ & 86 & 91 & $\mathrm{EtOH}$ & 3 & 4 \\
$\mathrm{C}_{2} \mathrm{H}_{3} \mathrm{CN}$ & 60 & 73 & $\mathrm{H}_{2} \mathrm{O}$ & 2 & 1 \\
$\mathrm{CH}_{3} \mathrm{COOH}$ & 32 & 35 & $\mathrm{DMSO}$ & 1 & 1 \\
$\mathrm{CH}_{3} \mathrm{NO}_{2}$ & 69 & 64 & $\mathrm{C}_{6} \mathrm{H}_{0}$ & 16 & 11 \\
$\mathrm{HCOOH}$ & 7 & 16 & Isooctane & 10 & 7
\end{tabular}

a) The yields are based ob CAN used. 
その理由としては，この反応が不均一反応であるため溶媒が硝 酸アンモニウムセリウム $(N)$ またはそれに由来するセリウム $(N)$ 銷体に対してある程度の溶解度を与えること,アルケンとの反応 を進行させるのに必要な適当な極性を有することなどが考えられ る。しかしこの系はアルケン一酸一非酸溶媒の三成分系ともいえ るものであり，かなり複雑な様相を示すために，溶媒に関する種 々のパラメーターと, 目的とする生成物の収率との間に定量的な 相関を見いだすことは困難である。

\section{7 結 睔}

以上の結果からこの反応は, セリウムに配位している硝酸イオ ンがギ酸などのカルボン酸のカルボキシラートイオンによって配 位子交換を受け，次いでこの硝酸イオンはさらに他の登絜酸化物 に分解し，そのものがアルケンの二重結合を攻撃する反応である ことが判明した。

この反応は, 現在, セリウムをそのキャリヤーとして用い, 地 球環境污染の根源の一つである窒素酸化物を周囲にまき散らすこ となく反応系中で in situ に発生させることによって，炭素一炭素 二重結合にニト口基を導入する方法を棈築したという意味を有す る。ただ，基質を最初に攻整する窒素酸化物がどのようなものか， セリウム錯体が空素酸化物のキャリヤー以外に触媒としても機能 しているのかどらか, ニトロアルケンとニトロアルコールのつく
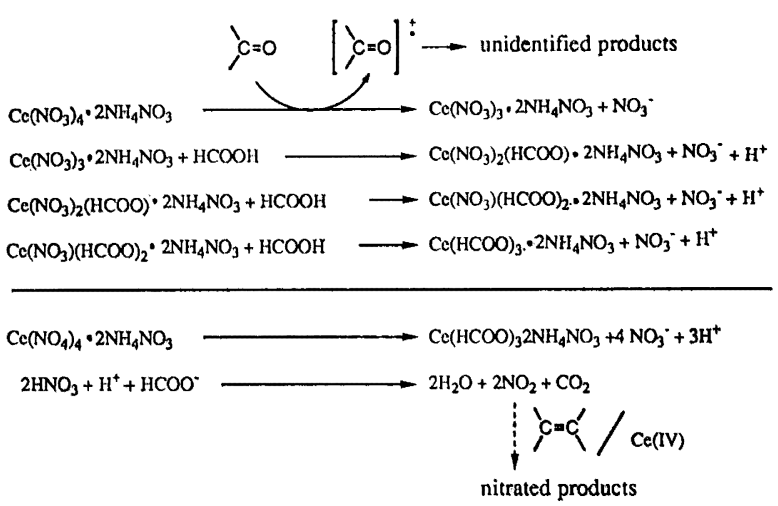

り分けがどの程度まで可能なものかなどの問題はなお残ってお り、さらなるテーマとして研究が続けられている。

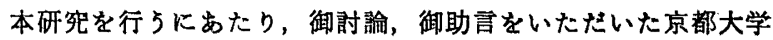
化学研究所大野惊吉教授, 岡信三郎名誉教授，硝酸七りウム(N) アンモニムを提供いたたいたセイミケミカル株式会社ならびにセ リウム化合物の分析に御協力いたたいたセイミヶミカル株式会社 桧山 進部長に梁謝します。

\section{A Special Edition \\ for Lanthanide Chemistry}

\section{Ammonium Cerium Nitrate Mediated Nitration of Carbon-Carbon Double Bond}

Takashi Sugryama

Institute for Chemical Research, Kyoto University; Uji-shi 611 Japan

It has been found that there are some interesting features in the ammonium cerium( $\mathbb{N})$ nitrate mediated nitration of carbon-carbon double bond, and they were investigated in detail. (1) Carboxylic acid such as formic acid is required to promote the reaction. (2) In addition to the substrate, ammonium cerium( $\mathbb{N})$ nitrate, carboxylic acid, and solvent, an appropriate additive such as carbonyl compound which does not have an electron-withdrawing moiety is required. (3) Ammonium cerium(N) nitrate has been converted into cerium(III) formate in the course of the reaction. (4) The present reaction, also, proceeds in the presence of ammonium cerium(III) nitrate. In this case, the additive is not necessary, but the yields of the products are not satisfactory. These results suggest that, in the present reaction, $\mathrm{NO}_{3}$ ligands on the cerium are replaced by formate anions, then resulting free nitrate ion decomposes into the nitroxides in the vicinity of cerium ion, which attack the carbon-carbon double bond in \substrate. 